Euskal ikerketen aldizkaria | Revue d'études basques |

Revista de estudios vascos | Basque studies review

Numéro Spécial 1 | 1999

Les lettres basques au temps d'Axular (1600-1650)

\title{
Axularren erretorikaz
}

\section{Patxi Salaberri Muñoa}

\section{OpenEdition}

Journals

Édition électronique

URL : http://journals.openedition.org/lapurdum/1602

DOI : 10.4000/lapurdum. 1602

ISSN : 1965-0655

Éditeur

IKER

Édition imprimée

Date de publication : 1 octobre 1999

Pagination : 119-142

ISBN : 2-84127-157-9

ISSN : $1273-3830$

Référence électronique

Patxi Salaberri Muñoa, « Axularren erretorikaz », Lapurdum [Linean], Numéro Spécial 1 | 1999, Sarean emana----an 01 juin 2010, kontsultatu 31 janvier 2020. URL : http://journals.openedition.org/ lapurdum/1602 ; DOI : 10.4000/lapurdum.1602 


\section{Patxi SALABERRI MUÑOA}

\section{AXULARREN ERRETORIKAZ}

\section{SARRERA GISAKOA}

1.- Ez da, ez, erraza Gero-ra (Bordele, 1643) hurbiltzea, urrunegi geratzen uste baitira orduko garaiak, kontuak eta gaiak. Eta Axularren obrara hurbiltzen direntxoek ere, -zilegitasun guztiarekin, nork uka !- ez dute bazka bera bilatzen ez aurkitzen, gehienak hizkuntza arloa aztertzera hurbildu ohi diren arren. Izan ere, esparru linguistikoa gertatu baita erakargarrienetakoa azken mende erdian ; eta bideratutako ikerketek ere, bistan da, areagotu baino ez dute egin Axularren obra baloratzeko ikuspuntu linguistikoa.

Guztiarekin ere, literatur balioen kezkaz kutsatuta dagoenak normalean beste balore sendoagorik nahi luke Axularren lerroetara hurbiltzerakoan, literarioagoak-edo izan litezkeen baloreak nahi bada, idaztankera eta estiloa definitzeko balioko lituzketenak, garai hartako beste hizkuntzetako literaturetan erabili parametroekin pareka eta homologa litezkeen planteamenduak.

Jakina, literatur ikuspuntutik aztertu nahi izate horrek bestelako testu-argitzeak ere eskatzen ditu aurre-baldintza gisara. Eta hau, ezagun da, edizioaren finkapenaz, originaltasunaz eta bestez mintzatzen hastea da. Eztabaida eta arazo sakon eta luzeegiak nonbait, eta, bestetan baino areago, Axularren kasuan ez beti adostasuna dakartenak.

Adostasun falta horretan, esaterako, Axularren idazlanari antzematen zaion testu-dependentziaz jabetzean jaso ohi da lehenengo "masailekoa", hots, haren liburuko pasarte asko eta asko hitzez hitz itzuliak zirela konturatzean. Pasarte itzuliok Villasantek eta bestek identifikatutakoak baino biziki gehiago direla ohartzean, arazo horren lehen ondorio zuzena hauxe izan da eskuarki : ba ote du obra honek inolako merezimendurik edota erabilerarik ikerketa linguistiko hutsetarako biltegi erraldoi gisara ez bada ?

Originaltasunaren arazoa, beraz, liburua itzulpen hutsa dela diotenen irizpidetik (eta bada horrelakorik !) obraren balioa beste nonbaiten bilatu behar dela diotenenganaino planteatuko da, literatur arazo larriena bailitzen, eta gogoan hartu gabe ez Axularren hitzetan bertan dagoela kontu-zuritze garrantzitsuena (liburua “...etarik bildua" dela aitortzen baitu zintzoki), eta ez originaltasunaren kontzeptualizazioa XIX. mendeko zerbait dela. Gogoan hartu gabe, finean, literatur balorazioak beste nonbaiten bilatu behar duela bazkalekua.

Egia da tematikoki ere ez dela originalegia urdazubiarra. Haren obra guztia aszetika munduko liburuen parekoa da, eta inolaz ere ez -aitortu beharrik ez dago- beste hainbat hizkuntzatako harribitxi dramatiko edota narratiboen mailakoa. Baina horretan ere badirudi Vargas Llosa bezalako idazle baten lekukotasu- 
na behar dela kontuak dagokien tokian utzi ahal izateko. Berriki adierazten zuen legez, "gaiak ez du axolarik, dena baitago idazkera eta egituraren menpe". Idazkera eta egitura, bada, zinezko literatur balio gisara.

Baina, jakina, hitz horiek narratiba modernorako balio badute ere, galdera da ea berdin aplika lekizkiokeen hamazapigarren mendeko obra aszetiko bati.

Egitura aldetik behinik behin, garbi dago erabat hertsiak ohi zirela horrelako obra gehienak eta nekez aurki litekeela haietan berrikuntza azpimarragarririk. Baina Axularren kasuan egiturarena originaltasunik bilatzeko aitzakia gertatu ez bada ere, ezaguna da aspaldidanik agertu dela arazo gisa, obraren bene-benetako arazoa (?) antolamenduan bertan (nahasmenduan, hobe!) baitzegoen autore askoren esanetan : nolako testu korapilatsua Eta ez hori bakarrik : urdazubiarrak hasieran eskaini nahi zuen bigarren partea bera ere nahasirik aurkezten bide zen liburuaren barrenean, horrek sortu anabasa guzti (ar) ekin! Intxauspe eta Lafitteren "ortopediak" liburuari bere jatorrizko taxua emateko saioak baino ez ziren izan.

Baina arazoa obraren antolamenduan zegoen zinetan ? Ala XIX-XX. mendeko irakurleon aurriritzietan?

Suhartasunik, grinarik eta apasionamendu gehiegirik gabe irakurri ondoren, ez dirudi bertan antolamendu arazorik dagoenik. Jakina, ezin ahaz daiteke egitura eta antolamendurako "logika" eta koherentzi irizpideak XVII. mendeko autore batenak direla eta egun saiakera arloan erabili ohi direnak ez bezalakoak ziurrenik. Edonola ere, Gero liburuak badu koherentziarik, "logika"-rik, eta ez dago orduko aszetika liburu gehienen taxutze irizpideen azpitik inolaz ere. Eta hori frogatzeko lekuko ospetsurik beharko balitz, handik ehun urtetara Larramendiren adimendu eta logika sakonak argitaratu iritzia mahaira liteke lasai asko, andoaindarrari ez baitzitzaion "arraro" iruditu Axularrek eskainitakoa : "[...] oxala huviera dado à luz la segunda parte, que ofrece al principio al Lector" (Diccionario trilingüe..., xxxv or.).

Guztiarekin, egituraren aspektuak literatur balio izan daitezkeen eremu batera hurbilarazten du ikerlea, izan ere antolatze koherentzia sistematikoa atzematen baita berehala kapituluetan barrena, sermoi klasikoen egiturarena hain zuzen. Ohiko terminologia erabiliz, honako hau genuke eskema orokorra : lehenengo lectio edo gaiaren aurkezpena (ez beti modu zuzenean egina). Aipamen baten bidez egiten da (aipamen biblikoak batik bat) nagusiki. Zenbaitetan beste autore edo auctoritates batzuez baliatzen da urdazubiarra. Bigarren epe batean tractatio edo dilatatio delakoa genuke, argumentazioa eta garapena alegia : adibideak, konparazioak, irudiak, etab. Amaierako peroratio edo konklusio izenekoan, ohi bezala, gaia zein izan den oroitaraztea eta irakurlearen barnea hunkitzea izango dira xedeak ; elementu desberdinak antzeman daitezke bertan, bataren edo bestearen azentua kapituluen arabera azpimarratuko delarik : laburbiltze edo recapitulatio delakoa, irakurleari zuzendutako galdetegi hunkigarri modukoa, bizimodua edo puntu konkreturen bat aldatzeko eta onbideratzeko ("konbertitzeko") eskaera, etab.

Antolamendu zinez sistematizatua Sarako idazle-predikariak barneratua zuena eta, ozenki baino ozenkiago, Erretorikaz mintzatzen dena, jendea konbentzitzeko teknika eta arte ikasiaz hain zuzen. 
Eta liburu barneko prosaren erritmoaz eta musikaltasunaz ohartzeko gaitasunik izango ez bagenu ere, aurrekoaren ondorioz, zinezko litzateke pentsatzea teknika horren sistematizazioak idazkera arloan ere izango duela eraginik eta presentziarik. Izan ere, idaztean, jendearen jokamoldeak aldarazteko idatzi zuen Axularrek, onbideratzearen beharraz komentzitzeko. Eta komentzitzeko, ezaguna zen eta da modu onak erabili behar direla, gauzak eta argumentuak era ahalik ederrenean azaldu! Hizkuntzaren baliabide estilistikoez jabearazi eta egokiro erabili, azken batean. Erretorikaren esparrua eta eginkizuna, beraz.

2.- Axularren erretorikari buruzko argitzapenek, ez da zalantzarik, haren aukera estilistikoez ere hitz egingo dute eta haren -horrela nahi bada- literatur balioez mintzatuko. Eta horretan letzake batik bat urdazubiarraren planteamendu erretorikoari eman beharreko inportantzia.

Jakina, urdazubiarrak Erretorikaren tekneaz duen ezagupena eta egiten duen erabilera ikusteko proba-toki egokiena esparru elokutiboa da, idazkerarena. Arlo honek, inventio eta dispositio izeneko atal kanonikoek ez bezala, ez du hipotesi eta fikzioetarako lekurik, idatzita dagoenaren konstatazioa baino ez baita.

Konstatazioaren ildotik, bada, eta aurrerapen gisara, zinez esan daiteke Axularrek erabilitako Erretorika mota eliz eginkizunetarako egokitutako erretorika eklesiastikoa dela. Honek, egia da, teknika multzo bat jartzen zuen idazlearen eskuan, baina gero erretoreek (idazle zen predikari) modu bateko zein besteko hautaketa eta erabilera egin zezaketen.

Ondorioz, Axularren "hautaketan" ere eskema elokutibok baditu, berez, modu batekoa bestekoa bainoago izateko arrazoi zehatzak eta, aldi berean, "baldintza" gisako izan daitezkeen faktoreak ere. Horiek guztiek testuaren moldaketa formala eta konkretua ematen lagunduko zuten.

Oro har, Gero liburua aszetikako lana den heinean, zehatz bereiztu beharko lirateke berezko diruditen bideratzaileak, batetik, eta "pragma"-tikoak edo diren faktoreak, bestetik. Horrela, edozein predikarik berbaldia ederragotzeko izan ohi zituen asmo arruntez gainera, Axularren prosaren alderdi elokutiboak badu bat, berezko deitu duguna, aszetikaz diharduelako ezinbestean isladatu behar dena eta, neurri handi batean, testuaren bideratzaile bihurtuko dena : irakurlearen baita hunkitzeko premia. Bestalde, testuaren eraketak berak erakusten duenez, eta, neurri handi batean, ohiko predikarien "ofizio"-aren ondorioz, bada Axularren elokuzioan ahozkotasunaren fenomenoarekin hertsiki lotua dagoen bigarren bideratzaile berezi bat ere, ahaztu gabe, jakina, hizkuntzari berari zor bide dakiokeena.

Ahozkotasunaren munduaren garrantzia berebizikoa da urdazubiarraren prosa ehuntzeko orduan. Alde batetik, ahozkotasunean murgildutako kultura zen XVII. mendearen hasierakoa euskal eremuetakoa, horrek zituen ezaugarri (batzuk arrazoi) guztiekin : liburu gutxi euskaraz, irakurle eskasia edota egin gabea ; euskaldun huts asko, beste hizkuntza batean ezin alfabeta zitezkeenak, etab.

Egoerak, jakina, irakurketa kolektiboak egitera bultzatzen zuen ezinbestean : batzuk irakurri, besteek entzun. Horren adibide garbia dugu Materreren ondoko pasartea : 
Goicean demborac hala emaiten duenean, çuec itsasoan çabiltçaten Marineloc bil çaitezte elkar gana, iar çaitezte belhaurico, eta ceuen gogoac Iaincoa gana ailtchaturic, eta ceiñaturic, erran eçaçue : Pater noster : Aue Maria : Eta Credo, latinez edo Euscaraz.

Eta hauquen ondoan erran beça çuetaric batec appur bat gora eta haguitz orai hemen ibenico dudan othoitza: Eta bitartean eduqui beçate bertcec ere hartan gogoa, ençun beçate, edo norc bere liburuetan ixilic iracur beçate, ceren estimatcen dut ez-tela icanen bat-ere iracurtcen daquien marinelic liburu haur içanen eztuenic (Materre, Dotrina Christiana, $327-328$ or.).

Era berean, ordurarteko idatzizko tradizioaren zati handi bat bertsotan egina zelako, hots, kantatua, kontatua eta buruz ikastekoa prestatua. Beste modu batez esateko, ahozko parametroen bidez burututako literatura ahozko tradizioan txertatua. Orobat, eta prestakuntza erretorikoa zela medio, ezin da ahaztu idazle baino lehenago sermoilari agertuko zirenek ahozkotasunaren esparruko baliabideen pisua islatzen zutela etengabe beren prediku eta testuetan.

Ildo horretatik, gogoratzekoa da irakurtzen zuena entzuten ohitua izaten zela predikaria : ozenki irakurtzeko prestatzen zituen sermoiak, buruz ikasten bide zituen eta gero predikatu (= ahoskatu) egiten zuen. Elizgizonak brebiarioa ozenki irakurtzen ohituak zeuden, ahoskatzen behinik behin. Belarria, beraz, prosaren modulatzailea.

Bigarren faktore bideratzaileaz ere, hots, hunkigarri suertatzeko premiaz, pare bat hitz. Aszetika esparruko testuei dagokienez, "hunkigarritasuna" irakurleen barnean eta afektuetan eragiteko premiarekin loturik dagoela esan daiteke. Ohiko docere eta deleitare izenekoak preziatzen ziren sermoien eginkizun baziren ere, movere izango zen benetan predikariak bilatu behar zuen xedea, entzule-irakurleen "konbertsioa" ahalbidetuko zuen "mugimendua" azken finean. Jakina, predikuetako helburu hori -eta urrun-hurbiltasunak ahaztu gabe- areagoturik azaldu behar zen bereziki aszetikaz ziharduen liburu batean.

Helburuok erdietsi ahal izateko erretorika eklesiastikoak oso modu zehatzean zituen garatuak hainbat baliabide. Horiek guztiek, zer esanik ez dago, izaera zenbaitetan bortitza, zenbaitetan leunagoa, baina betiere "hunkigarria" eransten zioten testuari.

Kanpotik ikusita ere elementu nabarmenak dira horiek eta garapen modu bereziak ekartzen dizkiote obrari. Izan ere, argumentazioan zehar anplifikazioari eskaintzen zaion funtzioa areagotuta geratzen da hunkipenaren atal honetan hartzen duen egiteko berriarekin.

Halere, afektuetan hunkitzeko ohiko bidea anplifikazioarena bada ere, ez dira faltako, erretorika klasikoan figura edo irudi bezala agertzen ziren beste hainbat, hots, errepikapenak, jarraiango galderak, harridura perpausak, apostrofeak, hiperboleak, etab.

Hori dela eta, zalantzarik gabe esan liteke Axularren liburuak faktore honi zor diola una da edozein hizkuntzatako literatur prosaren ereduaren eraketak dituen zailtasunak bertso edo neurtitzaren inguruko munduak dituenak baino biziki handiagoak direla. Azken honen ohiko egitura neurtuak (gehiago-gutxiago neurtuak, esan nahi baita) eskatzen dituen erritmoa eta musikaltasuna, esaterako, elementu erraztaile dira literatur hizkuntza sortzerakoan. Prosak, ordea, antzeko ezaugarriak (oreka, erritmoa, etab.) behar dituen arren, ezaugarri horien tratamenduan 
bertsoaren eremutik aldendu beharra du, harekin konfunditua izateko arriskurik gerta ez dakion.

Ohartua zen horretaz Erretorika klasikoa eta bideak ere jarriak zituen prosaren hizkuntza, neurtu gabea izanik ere, erritmikoa suerta zedin. Handik, beraz, erritmoaren oinarrizko osagaia elementu errepikakorra izatea, testuaren azpian etengabe "jotzen" duena baina garbiegi antzeman ezinezko bihurtzen den errepikapena. Dena den, teknika erretorikoak horretarako aurrikusi zituen baliabideak era desberdinetakoak izango ziren, nahiz garrantzitsuenetakoak periodoen eta kadentzien1 inguruan garatuko ziren.

\section{AXULARREN PROPOSAMEN ELOKUTIBOA}

Axularrek erretorikak eskaintzen dituen baliabide askotatik hartuko duen arren, badira eskema batzuk beste batzuk baino modu ageriagoan agertuko direnak -testuaren xede-izaerak behartuta inondik ere-, guztien konfluentziatik nolabaiteko egitura erretoriko bereziak sortuko direlarik ${ }^{2}$.

Urdazubiarraren prosaren lerro elokutiboak definitzeko baliabide azpimarragarriena aipatzekotan, "errepikapenaren printzipioa" nabarmenduko genuke ezaugarri gisa. Era berean, elementu guztiak integratzen saiatuko bagina, ondorio gisa ahozko parametroekin zerikusia duten edergarriak lirateke nagusi, liburuaren pasarte askoren elkarrizketa-konformazioa barne. Eta horren barnean ere baliabide fono-erritmiko errepikakorrak izango dira gailenduko direnak, ondoko lerrootan ikusiko den bezala.

\section{Erritmoaz eta kadentziaz}

Ezaguna da prosak erakusten duen erritmoa haren egituraketarako erabili baliabideei esker lortzen duela nagusiki (Kayser 1992, 346). Poesian ez bezala, prosan nekez gertatu ohi da aurretik prestaturiko parametroen barnean idaztea, hau da, hitzak, autoreak aldez aurretik buru-ezpainetan darabilen musika edo erritmo mota zehatz bati egokitzea. Horrexegatik, baliabideak ere bestelakoak ohi dira, batzuei besteei baino garrantzi gehiago emango zaielarik, autorearen aukeraren eta hizkuntza bakoitzaren senaren arabera.

Axularren kasuan, obraren erritmo nagusia gaiak, argumentazio motak eta prediku-egituraketak bideratuko dute bereziki, ahaztu gabe, noski, autoreak egiten duen "hautaketa" erretorikoa, aurreko faktoreekin bat dagiena, eta ohiko baliabide fono-erritmikoak.

Urdazubiarreren prosak erakutsiko dituen erritmo mota nagusiak bi izango dira : batetik, Gero-n garatzen den argumentazioaren ereduarekin bat datorrena eta, bestetik, predikazioaren helburua den movere delakoarekin lotua dagoen erritmo hunkikorra. Jakina, orri kopuru eskergagatik bakarrik ez bada ere, Axularren prosan antzematen den erritmo nagusia argumentatzaile deiturikoa izango da, aipatu lehenengo motari erantzuten diona. Horren arabera, konparazioen bidezko "arrazonamendua" erabiliko da ideien garapenerako.

Horrelakoetan, periodo egituraketa da formalki isladatzen dena, protasi eta apodosiaren oinarrizko eskemaren gainean eratua. Eta, oro har, atal kopuru desberdina egon daiteke batean zein bestean, barneko adarreztaketarik ere suertatzen 
delarik (plurimenbrazioak sortuz). Guztiarekin, elementuak ez dira bizpahiru atal izatetik igarotzen, eta normalean konparazio, baldintza edota denborazko perpausen egitura bikoitzaren arabera eratuak ohi dira.

Dena den, azpimarratzekoa da honelako egiturak eratzeko orduan Axularrek erakusten duen orekaren eta erritmoaren zentzu klasikoa. Horrela, konparazio huts bat den ondoko adibidearen lehen parteko atalak era neurtuan joango dira tentsio erritmikoa sortuz eta hedatuz :

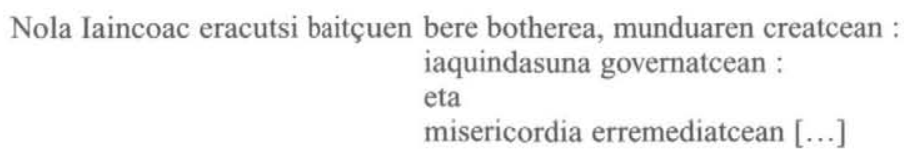

Ikusten denez, atal paraleloen luzerak berak markatzen du konparazioaren bidezko tentsioa. Gero, bigarren partean, konparatua izan denaren egoera egitura sintaktiko paraleloetan burutuko da, periodoa poliki-poliki ahulduz eta erremediorik gabe bukatuko bailitzen :

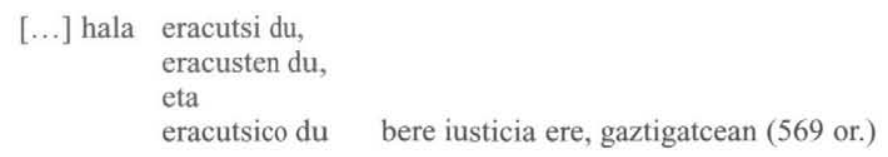

Eredu argumentatzaile luze, lasai eta orekatu horrekin batera, tradizio eklesiastikoak oso gogoko eta ohiko zuen mugimendu "latza" ere agertuko da Axularren prosan, arritmiko samarra baino zinez sarkor, hunkikor eta pertsuasiboa.

Estilo solte honek Axularren obran zehar presentzia nabarmena izango du kapituluetako hainbat une berezitan, batik bat irakurleari zuzendutako pasarteetan. Enumerazioak, pilaketak, paralelismoak eta antitesiak izango ditu ezaugarri nagusi. Eta, jakina, ez dira faltako irakurlea inplikatzeko galdera eta harridurazko formulak ere.

Erritmo bortitza izatera iristen den mugimendu honetan gehiago azpimarratuko da ideien indarra, prosaren oreka baino, ondorio gisa dinamika bizia agertuko delarik $^{3}$ :

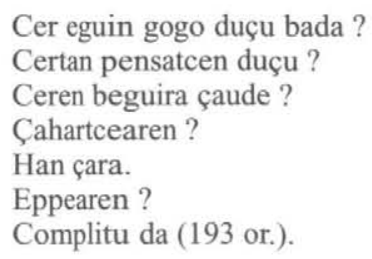

Oro har, esan genezake Axularren prosa erretorika klasikoaren elementu periodikoa erabat galdu gabe duen estiloaren eta predikazio kristauak ezaugarri duen eredu arritmiko-emotiboaren uztartze ahaleginaren fruitua dela, nahiz eta, egia da, bide erretoriko klasikoetatik aldentzen eta, aldi berean, finkatzen doan saio bezala ere plantea daitekeen, prosak erakusten dituen baliabide estilistiko "herritarrak" (esan nahi baita herri mailan hobetsi eta erabiltzen direnak : paralelismoak, antitesiak, hoskidetasunak, aliterazioak, etab.) horren lekuko hobezin direlarik. 
Esan gabe doa : testu barneko egitura sintaktikoak estilo horien bideratzaile izango dira, berek baitaramate berekin erritmoaren erantzukizunaren alderdi garrantzitsuenetakoa (esaldi motzak, bortitzak, arritmikoak, batetik, eta perpaus luzeak, lasaiak, argumentazio eta narrazio denborakoak, bestetik).

Horren kariaz, obraren planteamendu argumentatzaileak forma periodikoen erabilera ziurtatuko du, oinarrizko eskema -protasia edo osagai tentsio sortzaileak eta apodosia edo tentsioaren bukaera- modu desberdinetan emango delarik. Horretarako egitura sintaktiko ezberdinez baliatuko da urdazubiarra.

Menderakuntza eremuan, esaterako, Axularrek era guztietako egiturak darabiltza. Alabaina, adierazitako argumentazio garapenaren ildotik jarraituz, kausazko egiturak eta konparazioak ahalbidetzen dituztenak nabarmendu beharko lirateke batik bat. Nahiz prosaren erritmo erretorikoan ere garrantzi handia duten, bestelako egiturak, argumentazioaren ikuspuntutik behinik behin, ez dira hauek bezain emankorrak.

Maiztasunaz den bezainbatean, Geron zehar "zeren" lokailuaren bidez osatutako egitura kausalak dira gehien agertzen direnak (inoiz kapitulu berean 45 aldiz azaltzeraino). Maiztasun honek, dena den, testuaren izaera suasorioa erakusten du nabarmenkiro. Horrela, zerbait baieztatu edo adierazi ondoren, azalpena edo arrazoia agertzeko beharra izan ohi du idazleak, irakurlearengan lortu nahi duen komentzimendua areagotzeko :

Beraz carga badira ere, on dira orgac, velac, arrauac, hegalac, eta bai Iaincoaren legue sainduaren uztarria ere. Ceren uztarri haur, carga içanagatic ere, hunequin batean hobequiago, eta aisequiago iragaiten baitira mundu hunetaco trabailluac, eta atsecabeac. Cern Iaincoa bera leguearen emaillea, leguearen beguiratcen, eta complitcen laguntcen baitçaitu : eta hartaracotçat, uztartcen beçala baita gurequin (496 or. ; letrakera etzana gurea da).

Beraz, egitura hauen erabilera argumentatze moduak bideratua da oro har.

Bestalde, argumentatzeko bezainbeste, anplifikatzeko funtzio nabarmena hartzen dute Geron konparaziozko eredu sintaktikoek. Baina, horrezaz gainera, konparazioak kutsu praktiko eta argigarria eskaintzen dio argumentazioari, haren bidez irakurleak ulerterrazago duen mundu errealean uztar baitezake planteamendu erlijiosoaren mezua.

Konparazioetarako formulen artean, ez da falta egitura laburrekorik : "bezala", "pare", "paretsu" 4 edota "hala...nola" bezalakorik. Edonola ere, Axularrek gehien erabiliko duen eredua konfigurazio luzeko konparazioa gertatuko da, batik bat "nola.... hala (tan)..." formulapekoa (dagozkion aldaki guztiekin, hots, "nola...x", "x...hala", "nola... orduan", "nola... handik", etab.) :

Eta nola hartcen eztuen loreaz,

itchatchetquitcen eztenaz,

botean

edo

ninicoan galtcen denaz, ezpaita probetchuric : 


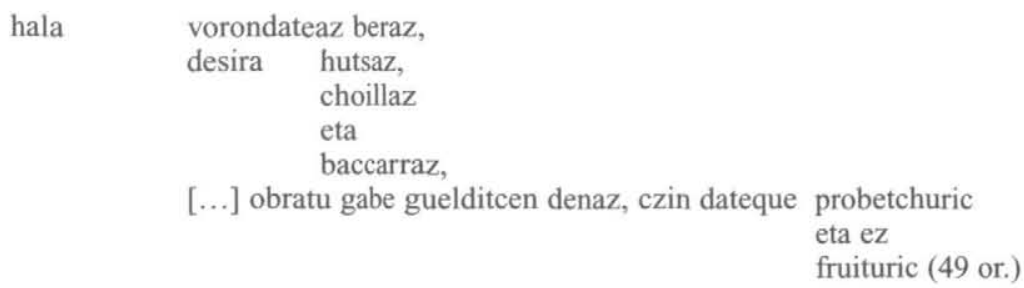

Azken egitura sintaktiko hauek eskaintzen duten grafikotasuna eta irudi multzoa dela eta, ezin hobeto ezkontzen dira eredu argumentatzailearekin eta testuaren egokitasun premiarekin. Horrela, gai aszetikoaren lehorra irakurlearen eguneroko errealitate biziarekin uztartzeko eta, garrantzitsuago dena, zailtasun kontzeptualak argitzeko erabiliko dira gehienetan.

Nolanahi ere den, egitura sintaktiko horiezaz gainera, bada bestelako nabarmenik ere ideien eta argumentuen garapenean barrena. Testuaren erritmoaren kariaz, esaterako, ohargarri deritzogu lotura asindetikoaz baliatzen den alborakuntza edo justaposizio egituraren presentziari, paralelismoak areagotuko duen egiturarenari hain zuzen. Formalki, estilo hautsi modukoa erakutsiko dute gehienek :

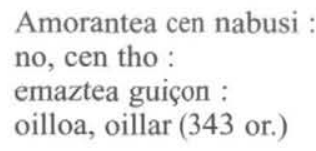

Bestalde, eta sailkapen zehatzetan sartu gabe, esan dezagun, ahozko teknika narratiboetatik hurbil nobait, "eta" lokailuarekin egituratutako perpausak nabarmenduko direla hainbat pasarte narratibotan, exenplu eta adibideenetan batik bat :

Eta hetan trabailla aracitcen cituen Pharaonec bere azpiko Iende hck, seiñalaturic bat bederari, bere eguneco lana eta sailla.

Eta escuaren ibentcea bera asco baçuketen ere : ordea lanhabesac, tresnac, eta obraren eguiteko gai guztiac ere, berèc bilhatu eta hornitu behar cituzten.

Eta halaric ere, ecin ausart citezkeyen arrencuratcera : halaco moldez ecen [...]

Eta halatan aitcinerat cargatuago cituen, lana berretu cerauen.

Eta hura guztia eguiten zuen [...] (26-27 or. ; letrakera etzana gurea da).

Bestalde, alderdi semantikoak fenomeno erritmikoan duen garrantzia ikusirik (testuaren dinamika bideratzen baitu), Axularren prosaren kasuan ere planteamendu erritmikoak lotura hautsiezina erakutsiko du kontatzen denarekin.

Mezu aszetikoa etengabe eta era askotara errepikatzean, esan daiteke pasarte gehienetan mailuaren funtzioa betetzen duela irakurle-entzuleen bihotzen gogortasuna apurtzera iritsi ahal izateko. Mezu errepikakortasun hori areagoturik edota apaldurik -eta ez da azken hau gure kasua- agertuko da prosari eskaintzen zaion erritmoaren arabera.

Garrantzi erabakiorra izango du faktore erritmiko horretan periodo eta esaldien bukaera motak : nola bukatzen den testu segmentua, horren araberakoa izango da irakurleak (edota entzuleak) kate mintzatuaren linealtasun horretatik jasoko duen azken inpresioa. Hortik beraz, klausula izeneko soluzioen5 garrantzia.

"Soluzio hobezin" horien eskema lortzeko teknikaren ardura, prosaren erritmoarena bezalatsu, idazle predikari bakoitzaren eskuetan zegoen. Eta egiteko hartan idazle predikariaren prestakuntza, erabilitako hizkuntza, berau bizitzeko 
modua eta, azken batean, sena estilistikoa bera gertatu ohi ziren aipatu "teknika" bideratzen zuten faktoreak, prosa guztiaren tonalitatea ahalbide zezaketenak.

Urdazubiarraren proposamena paralelismoan, luzapen kuantitatiboan (unitate lexikoena edota silabena) eta similikadentzian datza nagusiki, beroriek izango baititu egitura erretorikoen ezaugarri nagusi ${ }^{6}$. Jakina, bukaeretako luzapenaren soluzioa oso lotuta dago Axularrek predikari bezala bukaeratzat ulertzen zuenarekin. Horrela, etenketa baten aurrean, predikazioan berbaldiak erraz asko eskatuko duen edozein etenketaren aurrean alegia (periodo, perpaus edota esaldien bukaeran), idazleak erritmoa pausatzeko joera erakutsiko du, pentsamendua lasaituaz joango bailitzen.

Teknikoki pausatze hori paralelismoen bitartez burutuko du gehienetan, betiere paralelismoaren azken osagaia silabikoki luzeena den hitzarekin edota kolonarekin bukatuko duelarik (aditz laguntzaileak ere badu luzapen horretan tokirik, bukaerarako utz baitezake) ${ }^{7}$. Areago, grafikoki jarriz gero, nolabaiteko aurreratze kuantitatiboa ematen dela ikusiko genuke (lehenengo hitzak edota unitateak motzagoak bukaerakoak baino) :

Paga beçate beraz iragan duten aisia,

eta

alferqueria, presenteco penaz

eta

trabailluaz,

leheneco asea

soberania, oraico goseaz

eta

escasiaz ( 44 or.)

Egitura aldetik, Axularren jokamolde neurtu eta orokor horrek baditu erritmo orekatzaile diren aldaki interesgarriak, besteak beste, begien aurrean ere, simetria guztiak betetzen dituztenak :

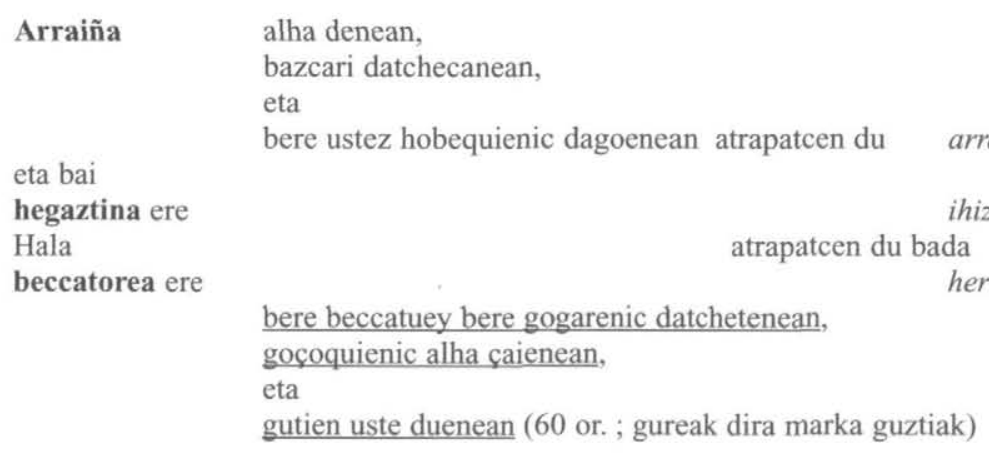

Mirail gisako paralelismo hirukoitza erakusten duen adibide honetan azpimarragarria da idazleak gogoan izan duen asmo orekatzailea. Horrela, hasiera emateko, perpaus zirkustantzialei dagozkien elementu motzenetatik luzeenetara abiatzen da lehendabizi, gero, konparazioaren bigarren unean alderantzizko prozesuari ekingo diolarik, hots, perpaus luzeenetik motzenera, bukaerako pausatzea prestatuko bailuen. 
Esan gabe doa, eredu klasikoen aholkuen bideetatik, Axularrek ere gogoan izan ohi ditu testu-segmentuen azken hitzen silaba kopurua, normalean hiruzpalau silabakoak hobesten dituelarik ${ }^{8}$.

Edozein gisaz, ez dira horretan bukatzen Axularrek kadentziak lortzeko darabiltzan konfigurazio nagusien ezaugarriak. Irakurleak berehala somatzen duen legez, saratartuak klausulen bukaera kuantitatibo hori bestelako edergarriz hornituko du beti.

\section{Edergarriez}

Gauza jakina da berbaldiaren edergarrien esparrua pentsamendu klasikotik iritsi zaigun doktrina erretoriko eta poetikoan balio eta transzendentzia gehien dituzten kontzeptuetako bat dela (Mayoral 1994, 24). "Ornatu" delakoaren bitartez, zegokion "tornuia" eman ohi zitzaion belbaldiari, batik bat prosa artistikoan, baina, jakina, bestelakorik ahaztu gabe. Izan ere, "bestelako" horren bidez helburu gisa irakurlearen barnea eta sentimentuak hunkitu eta jokamoldeak aldaraztea zuenak bereziki jakin behar zuen tekne erretorikoak eskainitako baliabideak erabiltzen.

Esan gabe doa : sermoiak eta idatz zitezkeen liburuak egokiago moldatuko baziren, predikariek haien iturri ziren testu sakratuak hobeto interpretatuko bazituzten eta, horren guztiaren ondorioz, sermoian planteatutako helburuak errazago lortuko baziren, ezinbestekoa zen baliabide haien erabilera zuzena.

Horretarako, eta gauzak erraztu ahal izateko, baliabideen artean mailakatze moduko bat egin ohi zen, betiere bitarteko gomendagarrienen artean erretorikaren edergarri klasikoenak eta eraginkorrenak aholkatzen zirelarik (besteak beste, aurkakotasunaz baliatzen zen teknikarena).

Ildo horretatik, Gero-ren ornatuaren ezaugarri nagusiak ere liburuaren izaera aszetikoak berak bideratu zituen lehendabizi. Horrekin batera, Axularrek behar eta iruditu bezalako "egokitasuna" eskainiko zion betiere, hau da, espero zuen irakurle motak eta egilearen xede pastoral-pragmatiko zuzenak eskatutakoaren araberakoa hain zuzen. Ondorioz, urdazubiarraren egitekoan ornatus facilis delakoa nabarmenduko da eta ez bestelakorik, hots, nagusiki koloreetan oinarritzen den edergarri-aukera, hitzezko irudi argietan batik bat, eta bakanka baizik ez eredu ilun edota metaforikoetan.

\section{Baliabide hunkigarriak}

Ez da ohiko predikarien eginkizun nagusia mezu baten erakuste hutsera mugatzen, mugiaraztea baitu sermoilariak helburu, hau da, bekatariaren "bihotza" hunkitu eta bertuterantz abiarazi hain zuzen (egiazko "konbertsioa" helburu, beraz). Eta xede hori erdietsi beharra zegoelako eman zitzaion horrenbeste garrantzia oratoria sakratuaren esparruari. Ondorioz, baliabideen eremua ere helburuen arabera sailkatu eta prestatuko zen.

Garaiko aszetikan ohi bezala, Geron lantzen diren afektu asko tematikoki bildurraren arlokoak dira : Jainkoaren bildurra sortzeko, infernuko penen bildurra izateko eta bekatuen aurkako gorrotoa pizteko, alegia. Bestalde, afektu positiboak edo izan zitezkeenak, Jainkoarenganako maitasuna esaterako, ia ez dira planteatu ere egiten, teorian liburuaren bigarren partea izan behar zuenerako geratzen 
baitzen egiteko hori. Beraz, hau guztiau liburuaren izaera aszetikoaren pragmatismoarekin uztarturik legoke, bizioak errotik atera eta, haien ordez, bertuteak lantzeko planteamenduarekin lotua hain zuzen.

Baliabide zehatzen esparruan, beraz, lehendabizi esan behar da teknika anplifikatzailea izan zela erretore eta predikari katolikoek gizakien baitara iristeko eta hunkitzeko erabilitako teknika garrantzitsuenetako bat. Axularren obrak ere anplifikazioa erakutsiko du oinarrietako bat, konparazioz, irudiz eta beste zenbait errekurtsoz baliatu baitzen anplifikazio teknika hain zuzen.

Horrezaz gain, ohiko ziren baliabideak ere prosaratu zituen urdazubiarrak bere liburuan, nabarmenetarikoa agian taxuketa dialogiko bezala ezagutzen dena delarik. Irakurlearekiko hurbiltasuna bilatzen da elkarrizketa antzeko egituratze horren bitartez; finean, liburua edo berbaldia eguneroko bizitza arruntean zuzenean ukitzen dituen zerbait bezala sentitzea baita helburua, irakurlearen inplikazioa edo, bestela nahi bada, haren "testuraketa". Ondorioz, taxuketa dialogiko hori afektuen esparrua hunkitzeko eta mugiarazteko biderik egokiena suertatuko da. Azpimarratu beharrik ez dago : oratoria sakratuak sistematikoki erabiltzen duen baliabide erretorikoa baino ez da hau, balio didaktiko handiko baliabidea alegia.

Egituratze horretan, baliabide erabiliena irudimenezko arrazonamendu arloko aldakiak izango dira nagusiki, batik bat dialogismo bezala ezagutzen dena, hots, elkarrizketa baten fikzioa sortarazten duena, nahiz eta bakarrizketa antzera ere molda daitekeen. Jakina, elkarrizketa moduko tratamendu hau era nahiko sistematikoan planteatuko da garaiko aszetika liburu gehienetan. Eta adierazi beharrik ez dago, Axularren Gero-n ere maiz asko erabiliko da, kapitulu gehienetan hain zuzen, batik bat estiloa bortitzago bilakatzen denean, galdetegiaren forma hartzen duenean, irakurlearenganako eraso izpirituala lortu nahi denean. Horrelakoetan, hausnarketa metodo bat da autoreak planteatu galdetegi zuzenarena, ordurarte tratatutakoaz irakurleari zuzen-zuzen galdetzearena.

Bestalde, liburuan zehar tartekaturik agertzen den dialogismoaren irudi honek beste guztiek baino garrantzi gehiago izango du, batik bat liburuaren beraren egituraketan hartzen duelako parte eta, aldi berean, ez delako irudi huts solte bat bezala geratzen.

Nolanahi ere den, erantsi behar da Geroren kasuan ez dela eredu dialogiko huts eta garbia aurkitzen, hartan oinarritutako formulazio zabal bat baizik, testuari zenbaitetan elkarrizketa kutsua isurtzen diona hain zuzen. Eredu horren bitartez, liburuan esandakoa irakurlearen errealitatera hurbiltzeko ahalegina erakusten du egileak. Orobat, xedetzat izan ohi du mezu-hartzailea gaiaren harian sartzea eta zuzenean inplikatzea.

Eta lehenengo begiradan ematen ez duen arren, zinez esan daiteke Axularren liburuaren zati asko direla horrela taxututa daudenak, baliabide dialogikoak une zehatzak izango baititu agertzeko eta eman nahi zaion funtzioa betetzeko. Horrela, argumentazioan baino maizago agertuko da perorazio zatietan.

Aurrekoarekin batera, nabarmena izango da Axularren prosan argumentazio aszetiko-erlijiosoan exenpluekin lotura estua duten irudien atala, besteak beste prosopopeiari dagokiona (maiztxo, hikako forma kolokialaz lagundurik). Azpimarragarria da, era berean, apostrofe izenekoaz urdazubiarrak dagien erabi- 
lera. Baliabide honek entzuleria berbaldian murgilarazteko elementu gramatikalak erabiltzen ditu, agintera eta, bakanago, bokatiboa hain zuzen. Erabilerari dagokionez, esan liteke aginduen arloko adibidez beteta daudela perorazio zati gehienak, betiere perpaus laburrez osatuak eta mezua ezin sarkorrago bihurtzen delarik.

Guztiarekin ere, afektuen mugiarazteko pentsamendu irudirik egokienak eta eredu dialogikoarekin ongien ezkontzen direnek esklamazioak eta galdera erretorikoak dirudite. Hauek biak izan dira literatura aszetiko-erlijiosoak maizen erabili dituenak eta irakurleak hunkitzera iristeko dramatismoa lortzen hobekien laguntzen dutenak. Horrexegatik, hain zuzen, baliatu izan dira bi-biak berbaldi guztien bukaera aldean, "konbertsioa" erdiesteko azken hitzak jaurtikitzen direnean, areagotu egiten baita testu segmentuaren kutsu bortitza jarraian esklamazio edo galdera sorta bat eransten denean. Guztiarekin, urdazubiarrak badaki diskurtsoaren bortiztasuna galderak eta esklamazio edo harridurazko esaldiak tartekatzen lortzen dela ongienik :

Cer içanen da orai nitçaz ?

Cer bide hartuco othe dut ?

Salbatuko othe naiz ?

Pontuaren latça :

Pausuaren gaitça :

eguitecoaren handia :

hersturaren hertsia, eta icigarria.

Cer eguinen du orduan arima ici harc?

Nor deituco du bere faboretan?

Norc escua emanen dio?

Nor helduco ?

Nor lagunduco çaica?

Nor bada ? (558-559 or.).

\section{Baliabide foniko-erritmikoak}

Berbaldi aszetikoak berezko dituen baliabide hunkigarriekin batera, ez da faltako prosaren eraketa formalean testu mota horren xedeei beste modu batez izango ez luketen ezaugarriak eskainiko dizkien edergarririk. Horien guztien artean, erritmikoki eta fonikoki ere funtzionamendu berezia itsatsiko diotenak nabarmendu behar dira, guztiak nagusiki "errepikapen" printzipioaren inguruan harilkatuta daudelarik.

Eta obran azaltzen diren fenomeno interesgarrienak ulertu nahi badira, ez da zalantzarik, azpimarratu egin behar da "errepikapen" printzipio horren garrantzia. Paralelismo kontzeptua ${ }^{9}$ ere printzipio horren ulerpena errazteko erabil liteke, eskema berdintasuna edota antzekotasuna duten egiturek ("berdintasun" kontzeptuaren oinarrizko premisa, alegia) gutxienez bi osagai edo atal "errepikatu" baitituzte.

Printzipio horren arabera, beraz, aurkeztuko dira esparru honetako baliabideak, betiere hizkuntz maila ezberdinen arabera eratuta, Dijk-ek eta bestek aholkatu bezala10. Esan dezagun aldez aurretik, dena den, Axularrek oso gogoko dituela ahozko eta idatzizko tradizio luze, oparo eta eraginkorrak eskainitako baliabideak. 
Lehenik eta behin, eta arlo sintaktikoan murgilduz, aitortu behar da Axularrek oso gustuko duela isokolona. Irudi hau bi edo testu segmentu gehiagoren artean luzera eta egitura sintaktiko berdintasuna adierazteko erabili ohi da. Jakina, honelako irudi batek berezko du plurimenbrazio egitura, eta, ondorioz, eredu desberdinak agertu ohi dira autoreen lanetan, norberaren estiloen araberakoak.

Axularrenari dagokionez, esan daiteke bi direla gailentzen direnak : bi eta hiru atalekoak hain zuzen (bimenbrazioak eta trimenbrazioak). Lehehengoak oso gogoko izango ditu ideiak kontrajartzeko eta antitesiak burutzeko.

Atalbikoek, normalean, formulazio ezberdinak hartuko dituzte, maiz asko eredu parataktikoetan zein asindetikoetan oinarriturik agertuko direlarik. Guztiarekin, eta lortzen duten efektu hunkigarri eta estilistikoagatik, bereziki azpimarratzekoak dira egitura asindetikoetan Axularrek egin ohi dituen lotura anaforikoak :

Orai hamar beccaturequin diharducaçu, guero ehunekin iharduqui beharco duçu.

Orai urthe baten edo biaren usantça gaixtoa duçu, guero hogoyena edo berrogoyena içanen duçu ( 84 or.).

Formalki, bimenbrazioetan luzera guztietako perpausak aurkitu ahal izango dira oro har. Edonola ere, egitura berdintasuna erabatekoa izan arren, atal bat bestea baino luzeago gerta daiteke betiere konplexutasunaren arabera, hots, atal luzeak besteak ez dituen hainbat elementu barnehar ditzakeelako hain zuzen (erlatibozkoak, etab.).

Baina atalbikoez gain, testuan ez da bestelako plurimenbraziorik ere faltako (hiru, lau... atalez osatuak), ederragoak baitziren klasikoen kanonen arabera. Horrelakoak elipsi kontestualez (zeugma-z, alegia) baliatzen dira maiz asko, aditzaren ezabaketaz batik bat :

Cen ederrena, eguin cen, itsusienik

bere gogarena gaizquienic.

Onhetsiena, gaitzetsienic ;

eta gorena, beherenic (139-140 or.)

Era berean, honelako plurimenbrazioetan beherago ikusiko den egitura anaforikoak garrantzi handia izan ohi du atalen arteko lotura gisara :

Nahi baduçu gueldi dadin etsaia, gueldi çaiteci,

nahi baduçu ichil dadin, ichil çaiteci.

Nahi baduçu sua iraungui dadin, egurrac edequi iatçotçu (293 or.)

Oro har, erabateko paralelismoa gauza ohikoegia ez bada ere, begi bistakoa da paralelotasun sintaktiko hauetan paralelismo lexiko-semantikoa gertatu ohi dela, maila bereko berdintasuna ere eman daitekeelarik (elementu zenbaiten errepikapenaren bidez : aditza bera, etab.). Izan ere, egitura berdintasuna dela eta, elementu errepikakorrak dira gailentzen direnak : lexikoa, egitura anaforikoak... eta, ezaugarri nagusi bezala, elementu homofonikoa.

Ildo beretik, arlo morfologikoko irudiak ere testuaren garapenean elementu ezberdinen errepikapenaren bidez izango dira sortuak, eta mezuaren efektuen gehiketaz gainera, erritmoaren mantentzea eta hotsen areagotzea erantsiko dizkiote prosari. Aldi berean, ezin ahaz daiteke irudi hauen garrantzia berbaldiaren jostura sintaktikoan, beraiek duten izaera errepikakorrean baitatza diskurtsoaren kohesioa hein handi batean. 
Geron ere errepikakortasun hedatu hori izango da prosa barne muineraino tindatuko duen faktorea, batik bat egitura anaforikoen esparruko irudien bidez. Jarraikako esapideen hasierako hitzaren edo hitz multzoen errepikapenean $[\mathrm{X} \ldots / \mathrm{X} \ldots]$ dautzan egitura anaforikoak prosa erretorikoaren baliabide ohikoenak direla esan daiteke, zinez erritmiko bihurtzen baitute berbaldia. Horrezaz gainera, konfigurazio anaforikoak lotura estua erakusten dute idazleak azpimarratu nahi duenarekin. Ideia edo mezu bat irakurle-entzulearen barnean tinko atxikirik gera dadila nahi denean, anaforak sarrera funtzioa edota eginkizun azpimarratzailea beteko du berbaldian, Axularrenean ikus daitekeen bezalaxe :

Hasico dira oihuz,

hasico dira deihadarrez, nigarrez eta marrascaz :

hasico dira bere ondico handiaren deithoratcen eta auhentcen :

hasico dira bere buruen maradicatcen, beguitarten larrutcen eta atçapartcen (607 or.)

Argumentazioaren linealtasunean oinarriturik, Axularrek zenbaitetan kate anaforikoak osatzen ditu, hots, serie ezberdinez osatutako kateak eta aurretik aipatutakoei nolabaiteko jarraipen argumentala eskaintzen dietenak. Ildo horretatik, denetariko adibideak aurki daitezke liburuan :

Orduan bai,

orduan onduco naiz :

orduan munduari guibela emanen diot, eta [...]. Baiña anarteraiñocoan

deçadan atseguin har,

deçadan mundua cerbitça :

naquion goça :

naquion behin $[\ldots]$ asse, eta asper.

Haur da oraico presuna gazten deliberamendua,

haur da hequen gogoa : eta

haur da adinean beçala, gaiñeracoan ere [...] (173-174 or.)

Guztiarekin, testu kohesioa dela eta, Axularrek egitura anaforikoez haratago egiten du kapitulu beten ehunduran garrantzitsu irizten dion esaldia errepikatzen duenean (interesatzen zaion aldaketa eginez, jakina). Ondokoak, esaterako, LIX. kapituluaren perpaus laburbiltzaile eta kohesio-emaileak dira :

Dembora gutiz eta laburzqui eguiten den beccatuari, emaiten çaica seculaco gaztigua ( 608 or.)

Dembora gutiz eguiten den beccatuari, emaiten çaica gaztigu lucea eta seculacoa (610 or.)

Dembora gutiz eguiten den beccatuari, emaiten çaica seculaco gaztigua (612 or.)

Ohargarria da, halaber, nola darabiltzan Axularrek elementu anaforikoa eta paralelismoa pentsamenduen antitesiak markatzeko. Honek, noski, areagotu egingo du prosaren izaera antitetikoa. Adibideak anitz badira ere, horietako luze eta interesgarrienetako bat 480-481 orrialdeetan aurki dezake irakurleak (Plazer da... / Gaitza da... egiturekin osatua hain zuzen).

Anaforaren alderantzizko egitura (...X/...X) erakusten duen irudi epiforikoak ere leku berezia du Axularren prosan, nahiz eta, maiztasunari dagokionez, egitura anaforikoa baino gutxiagotan agertzen den. Hala ere, adierazi behar da egitura epiforikoa aditzaren (batez ere aditz laguntzailearen) errepikapenez burutzen dela eskuarki (...da,...da ;...çaitçula,...çaitçula ; etab.) : 
Etsaigoan çaude :

amorantearequin çaude :

bertceren ona goraturik çaude (570 or.)

Adibiderik falta ez bada ere, eta normala denez, anafora eta epiforaren arteko uztartzetik sortzen den sinplokea (X...Y/X...Y) edota testu segmentu baten hasieran eta bukaeran hitz edo hitz multzo baten errepikapena (X...X) eskaintzen duen epanadiplosia bezalako irudiak aurreko paralelismo formak baino gutxiagotan agertzen dira Axularren prosan.

Gradazio delakoak, aldiz, interes berezia eskaintzen du Axularren prosan. Izatez, jarraikako anadiplosia baino ez da, hots, unitate sintaktiko bateko bukaeraren errepikapena ondoko unitatearen hasieran $(\ldots \mathrm{X} / \mathrm{X} \ldots \mathrm{Y} / \mathrm{Y} \ldots)$. Oro har, mailakako eskemaren arabera eratua da, berbaldia maila bakoitzean pausatuko bailitzen.

\author{
Lehenic hiltcen da haurtasuna : \\ haurtasunaren ondoan hiltcen da morrointasuna : \\ morrointasunaren ondoan hiltcen da gaztetasuna : \\ gaztetasunaren ondoan hiltcen da çahartasuna ; \\ çahartasunaren ondoan hiltcen da sentontasuna (62-63 or.)
}

Ikusten denez, hemen ere errepikapena da oinarria (ahaztu gabe, jakina, kasu honetan hitzen -tasuna atzizkiak suposatzen duena). Erantsi beharko litzateke irudi honek estrategia aldaketa suposatzen duela Axularrek darabilen eredu konparatibo-argumentatzailean, nolabaiteko planteamendu logiko-silogistikoa suposatzen baitu irakurlearentzat. Alabaina, ez da gehiegitan baliatuko duen irudia.

Beste aldetik, irudi morfologiko legez sailkatu ohi direnen artean ez dira faltako Geroko prosan erretorika klasikoan derivatio bezala ezagutzen zirenak (erro beretik datozen hitz desberdinak) eta Axularrek ezin gogokoago zituenak :

San Agustinec eztu conturic eguiten, aitcineco perseverantciaz eta irauteaz, finera baiño lehen, edo finean berean, fina finatu gabe finatcen denaz (457 or.)

"Hitz jolas" gisa definitu izan diren hauek maizkara azaltzen dira Axularren testuan. Besteak beste, unitate lexikoen arteko homonimia edota polisemia erlazioetan oinarritzen diren "jolas" irudi hauetatik guztietatik paronomasia arlokoak gertatzen dira emankorrenetakoak11. Ezaugarri bezala, hitzen eta hotsen arteko paralelismo efektu-sortzailea azpimarra daiteke.

Bestalde, eta aurrekoekin estuki loturik, arlo semantikoko irudiak letozke, batik bat hitz multzoei eta sinonimiari dagozkienak, hitzaren esparru honetan baitatza urdazubiarraren prosaren ezaugarri nagusietako bat.

Aurrekoetan bezalatsu, hemen ere errepikakortasuna izango da irizpide bideratzailea eta, haren arabera, berbaldiaren erritmoa bera izango da hain nabarmenkiro azpimarratua izan den hitz joritasuna eskatuko duena. Horrela, paralelismoak diskurtsoaren erregulatzaile erritmiko nagusi gisa agertuko diren moduan, hitz multzoak (bereziki sinonimoak edota esparru semantiko bereko hitz mulzoak) perpausen erritmoaren orekatzaile gisa azalduko dira.

Gauzak bere lekuan uzteko, gogora dezagun lehendabizi sinonimia dela ziurrenik historian zehar (eta batez ere hamasei eta hamazazpigarren mendeetan) hizkuntza eta testu mota guztietan gehien erabili eta hedatu den baliabidea. Agian horrexegatik hain zuzen, ez zen sinonimia erretorika eklesiastikoaz arduratu ziren prezeptu-emaileek -Trentokoaz geroztikakoek, batik bat- gogokoegi zuten irudia, 
balaztarazi beharreko fenomenoa gertatzen baitzen haren bidez sortu hizkuntza puztua. Ahal zen neurrian bederen, obra erlijiosoetan hitz eta kontzeptuen arteko erlazio biunibokoa bulkatu nahi izango zuten erretoreek, inolako fede-nahasketarik eta behar ez zen hanpadurarik ez gehiegikeriarik ere sor ez zedin.

Guztiarekin ere, Axular ohiko bide klasiko eta oparoetatik abiatu zen bere prosa taxutzean. Oro har, bada, egitura paraleloen errepikapena suposatzen zuen eredua izan zen berak oraingoan ere onetsitakoa. Ildo horretatik, joera zabala eta aberatsa atzematen zaio eremu honetan : sinonimia garbia egiten duten bikoteetatik-hasita intentsifikazio semantikoa dagiten egitura plurimenbre desberdinetako osagaietaraino, betiere tartean geratzen diren bimenbrazio ez-sinonimikoegiak eta plurimenbrazio sinonimiko estuagoetatik iraganik.

Inoiz azpimarratu den bezala, Axularren sinonimia-zaletasuna liburuaren izenburu luzean bertan antzematen da ${ }^{12}$. Ez bide zuen askietsi, esaterako, Etxeberri Ziburukoak liburuaren banaketarako erabili zuen formula motza (“[...] guztia bi partetan bereçia"). Horretan ere Axularrek beharrezko izan zuen hitz bikotearen beharra : "bi partetan partitua eta berecia", eta berdin aurrerago ere : "quidatcen da, eta aitcinatcen [...]".

Transmititu nahi duen mezua ulertarazten laguntzen duela jakin arren, Axularrek anplifikaziorako tresna bezala hartzen du sinonimia, ahaztu gabe, jakina, orekagarri ezin egokiagoa dela erritmoaren finkapenean.

Erabilera arloan, serie sinonimiko bitarrak eta hirutarrak nagusituko dira haren obran. Ondorioz, hiru elementu semantikoki berdintsuz (izen, adjektibo, aditz,...) osatutako multzoek markatuko dute prosaren oinarrizko erritmoa, paralelismo sintaktikoetan agertzen duen joera bezalakoa hain zuzen, baina hemengo hauetan, azken osagai bien artean eta emendiozko juntagailuaren presentzia konstateago izanik.

Ildo horretatik, Axularren prosan nekez aurkitu ahal izango da elementu erritmikoki esanguratsurik bakanka, plurimenbrazioak osatzen baizik. Eta horien artean, hirukoak dira Axularrentzat orekatuenak, mezua azpimarratzeko eta esaldia erritmikoki ongien ehuntzeko balio dutenak, batik bat bukaeretan :

$\begin{array}{lll}\text { Eta Ainguiru guztien } & \begin{array}{l}\text { lehena, } \\ \text { aitcindaria, } \\ \text { eta } \\ \text { aguintaria, eguin zen }\end{array} & \begin{array}{l}\text { Deabru, } \\ \text { eta } \\ \text { Deabru guztien }\end{array} \\ & \begin{array}{l}\text { buruçagui, } \\ \text { quidoin, } \\ \text { eta } \\ \text { capitain (139 or.) }\end{array}\end{array}$

Hiru atalez osatutako plurimenbrazioen nagusitasun horrek, dena dela, ez du kentzen testuan zehar arrunt bilakatzen diren bikoen presentzia, horiek ere oso gogoko baititu urdazubiarrak :

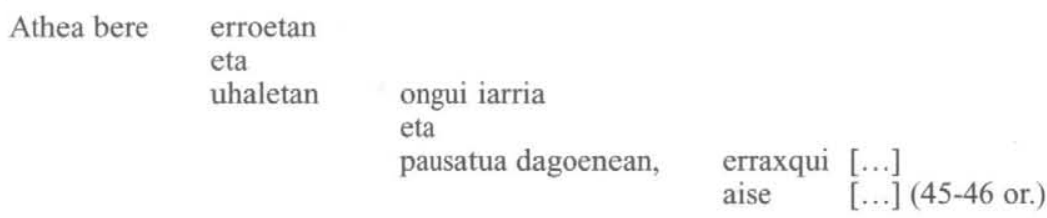


Horrekin batera, badira Gero-n barrena osagai gehiagoz eratutako serieak ere, batzuk besteak baino biziki luzeagoak gainera : "Ordea guelditzen den seiñalea, marca, notha, culpa, çorra eta obligacinoa, seculacotz guelditcen da" (613 or.). Halere, testu-segmentu edo esaldi berean plurimenbrazioen arteko konbinaketak ematen direnean, normalean hiru elementukoa izan ohi da besteei gailentzen zaiena, batik bat -diogun berriro- perpaus bukaeretan :

Presuna gazteen lehenbicico obra on [...] hetaric naiz çale,

eta

gura,

hec çaizquit on,

goço

eta

ezti (171 or.)

Halaber hiru elementuetako multzoekin osatuko dira gero urdazubiarraren prosa nabarmenduko duten "jauzi" edo gradazio moduko eredu ezagunenak (9 or.) :

[...] anhitz donu,

dohain,

eta

abantail suertez dotatu,

hornitu

eta

konplitu baitzaitu, adimendu eder bat, memorio handi bat,

eta

borondate onera,

ohorera,

eta

prestutasunera erori bat,

isuri bat,

eta

eman bat eman baiteratzu.

Hotsen eta hitzen jolasarekin batera, eta testu-segmentuaren erritmoaren barnean isosilabismoa nagusitzen ez denetan, azpimarragarria da hitzen luzerari, hots, silaba kopuruari Axularrek jartzen dion arreta, katearen hitz motzenak hasieran eta luzeagoak ondoren doazelarik (eta neurri bereko hitzak suertatzen diren hainbatetan -gehiegikeria ote ?- ondozkapen alfabetikoaren irizpideari jarraituz) :

$\begin{aligned} \text { Eta gueldituco dira, alde guztiz } & \text { dolutuac, } \\ & \text { etsituac, } \\ & \text { desconsolatuac } \\ & \text { eta } \\ & \text { desesperatuac ( } 607 \text { or.) }\end{aligned}$

Esparru semantiko honetako fenomeno berezi gisara, aipagarria da ditologia sinonimikoaren kasua, ezin garbikiago mintzatzen baita Axularrek lortu nahi duen efektuaz. Jakina den bezala, horrek beste ezer baino lehenago testuaren tratamendu erretorikoa erakutsiko luke nabarmenkiro. Hasierako "bere imaginara eta idurira" ( 21 or.) ditologia bibliko klasikotik beste guztietaraino ${ }^{13}$, Axularrek anplifikazioa eta prosaren erritmoaren erregulatzea bilatuko luke nagusiki. Ditologiatik hurbil dagoen bukaerako adibide honek modu ezin hobean laburbilduko luke funtzio erretoriko eta "kontrolatzaile" hori : 
"Hartan pensa ezazu, hartzaz egizu pensamendu, hasnaur eta gogoeta" (620-621).

Esparru semantikoaren barneko kasuistika garrantzitsuenarekin bukatzeko, gogora dezagun Axularren liburua planteamendu antitetiko baten inguruan ardazten dela oro har, guztiaren gakoa izenburuan bertan azaltzen delarik : gero. Horrek berak eta antonimo gisako funtzionamendua duen orain hitzak osatuko lukete liburuaren funtsezko izaera antitetiko hori.

Halaber, liburuaren izaera antitetiko orokor horrek antitesi irudi zehatzetan aurkituko du gero isla interesgarria ${ }^{14}$. Horrela, ideien kontrajartzeak nabarmenki azalduko dira antonimoen erabileraren alorrean ${ }^{15}$, unitate lexiko hauek gertatuko baitira ideien arteko gatazka kontrajarria garbienik azalduko dutenak eta antitesiak moldatuko dituztenak :

\begin{tabular}{|c|c|}
\hline Beccatu eguiten duenarentçat daducaçu Iaincoa, & $\begin{array}{l}\text { handi, } \\
\text { çabal, } \\
\text { franco, } \\
\text { liberal ; }\end{array}$ \\
\hline $\begin{array}{l}\text { eta } \\
{[\ldots] \text { prestuqui bicitcen denarentçat, estimatcen du }}\end{array}$ & $\begin{array}{l}\text { dela } \\
\text { hertsi, } \\
\text { mehar, } \\
\text { escas } \\
\text { eta } \\
\text { avaricios (148-149 or.) }\end{array}$ \\
\hline
\end{tabular}

Irudien sailkapen honekin aurrera eginik, esan daiteke arlo fonologikokoek ere errepikapenaren printzipioan dutela haien funtsa, zein bere modura eta gisara.

Oro har, Axularren prosan similikadentziarena izango da osagai "entzungarri"-aren inguruan ardazten den baliabide garrantzitsuena, hitz edota sintagma paraleloen amaieretan errepikapen fonikoa baitu etengabeko ezaugarri haren hizkerak.

Bestetan baino gehiago nonbait, azpimarratzekoa da kasu honetan urdazubiarraren "originaltasuna" ; izan ere, inguruko hizkuntzetan ez bezala, euskararen deklinabideak, latinaren antzera, homoioptotona baliatzeko aukera ezin hobea eskaini baitzion gure idazleari. Eta horrela, testuinguru guztietan sistematikoki azalduko den fenomenoa izango da bukaera flexiboen errepikapenarena. Adibideak, zer esanik ez dago, jarraian eta etengabe agertzen dira Gero guztian, eta ez dago bertan orrialderik sorta bat kasu adierazgarri ez duenik. Kasuistika, beraz, zabala da eta deklinabidearen kasuetara eta aditz flexio guztietara iristen da. Dena den, normalean paralelismoz eta bestelako errepikapenez lagundurik egon ohi da urdazubiarraren irudi klasiko hau :

Cer esquer uste duçu içanen duela, edo irabaci eguinen duela

çahar ecinduac etsaiari bidera harmaturic ez ilquitceaz ?

Arratsean etcherat goiz viltceaz,

eta

bihurtceaz?

Amorantiara gaztean beçala ez ioaiteaz ?

Dantçan

eta

iaucian ez ibiltceaz? (177 or.) 
Zenbaitetan, alabaina, badirudi Axularrek oso gogoko duela hitz bukaeretako homofonia bikoteka edo hirukoteka burutzea, hitz jarioarekin jolasean balego bezala eta nolabaiteko jauzi fonikoak eginez. Ildo horretatik, ohargarri deritzogu prosaren mugimendu latza edo izan daitekeena azaltzen duten pasarte luzeetan Axularrek erakusten duen similikadentziaren premiari. Balirudike baliabide morfologiko-testualen faltaren aurrean, testuaren dinamikak beste zerbait eskatzen diola idazlearen senari. Horrelakoetan, bertsoen hoskidetasunaren oihartzuna datorkio irakurleari :

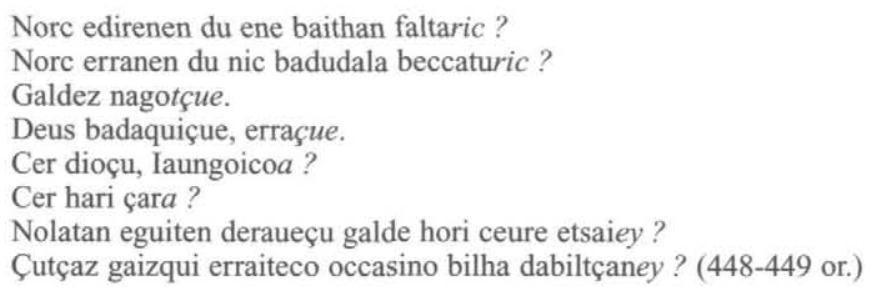

Guztiarekin ere, garbi utzi nahi genuke fenomeno homofoniko honen garrantzia Axularren idaztankeran, berau baita sistematikoena, hedatuena eta berariazko tonalitatea eta "kolorea" (erretorikoa barne) ematen diona.

Maiztasunean biziki apalago, hizkuntzak ez baitu horrenbeste aukera eskaintzen, homoioteleuton irudiaren erabilpena ere ugaria da : "habea, iabea" ( 5 or.) eta "onhest, modest" (177 or.) moduko paronomasikoak, "laguntça, [...] esperantça, [...] segurantça" (484 or), "gar, [...] nigar" (501 or.), etab. Homofonia areagotze horretan, Axularren testuan ez da faltatuko homoioptoton eta homoioteleutonaren bilketarik ere : "ausartciaric eta escudantciaric" (16 or.), "itsutasun haren eta gogortasunaren" (105 or.), etab.

Similikadentzia hertsiaren sailetik aldenduz, zenbaitetan Axular homofonia bokaliko hutsak (asonantziak, alegia) erabiltzera makurtzen da. Agindu, aholku, mezu eta baiezpen kategorikoetan batik bat, autoreak homofonia desberdinen beharra sentitzen bide du. Esan liteke hori egiten ez duen garrantzizko testu-segmenturik ez daukala. Eta, agerian denez, mota guztietako baliabideak uztartuko ditu esaldia orekatzeko eta, aldi berean, "efektista" bihurtzeko. Ildo horretatik, maizkara nabarmenki premiazkoa du egileak, paralelismoaz eta isosilabismoaz gainera, aliterazioa eta bestelako homofoniak baliatzea (gureak dira letrakera ezarrunt guztiak) :

Ordea norc erranen du zenbat balio duen orai hunec ?

Iraute,

iraupe,

eta

bitarte ttipi,

aphur,

labur hunec ? (156 or.)

Ikusten denez, lortzen den efektu erritmiko-musikala ez da kasualitatearen fruitua ; prosa arras "kontrolatua" da Axularren lumatik sortzen dena. Ondoko adibideak ere ezin argiago uzten du urdazubiarraren jokamoldea. Nabarmena da anaforez, hitz errepikapenaz eta isobokalismoaz baliatuz, eta perpaus barneko hitzen arteko distantziak (fonetikoak, batik bat) ahalik eta hurbilen mantenduz, egin daitekeen musika jolasa (gureak dira letrakera ez-arrunt guztiak) : 
Badu itsasoak bere chedea,

bere marra,

bere mugarria

eta

zedarri jakina, zein baita

$\begin{array}{ll}\begin{array}{l}\text { kosta } \\ \text { eta } \\ \text { kostako }\end{array} & \begin{array}{l}\text { sablea } \\ \text { harea } \\ \text { eta }\end{array} \\ & \text { legarra }(113 \text { or. })\end{array}$

Azkenik, aipatu adibide hauek beste puntu bat mahairatzeko aitzakia ere eskaintzen dute. Izan ere, Axularren prosa lan honetan, teorian bertsoei -neurkera erakusten dutenei, jakina- legokiekeen hoskidetasun ${ }^{16}$ moduko eredurik ere atzeman uste daiteke zenbait pasartetan. Berriro ere bertso edo poesiaren esparrutik zipriztindutako aztarnez eta ereduz ari gara.

Printzipioz fenomeno hau similikadentzia irudien barnean sartzeak arazorik ekarriko ez balu ere, zinez pentsa liteke beste zerbait gehiago dagoela horrelakoen azpian. Edo beste modu batez planteaturik, galdera da ea Axularrek ez ote zituen pasarte horiek gogoan zeuzkan neurri eta musika eredu konkretuen arabera moldatu eta egokitu, kadentzia erritmiko jakin batzuen arabera eratu hain zuzen. Azken buruan, nolabaiteko bertso ereduari jarraitzen dioten sekuentzien bukaeretako fenomeno homofonikoen aurrean geundeke.

Balirudike Axularrek nagusiki -baina ez esklusiboki- ahozkotasunaren munduko erreferentzia paremiko-poetikoen esparrukoak bide diren ereduak baliatzen dituela hainbat pasartetan, normalean formula sistemari atxikirik eta mezua tinko, labur eta "neurtu-errimatua" ${ }^{17}$ aurkeztuz :
Permititcen du Iaincoac,
munduan diren probeac,$$
5+3
$$$$
5+3
$$$$
\text { hey ongui eguinez, }
$$$$
\text { salba ditezin aberatsac (225) }
$$$$
5+3
$$

Horrelakoetan zail da atsotitz eta esaera zaharren esparrua ahaztea, etengabe agertzen baitira mundu horretako oihartzunak :

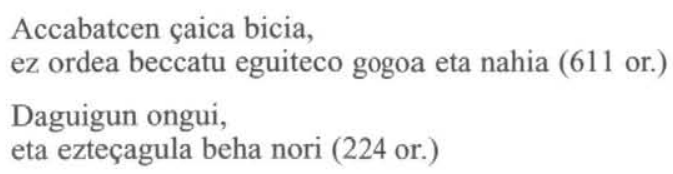

Eslogan modernoetan bezala, hauetan ere etengabe erabiltzen da nolabaiteko hoskidetasunaren eta kadentzia erritmikoen paralelismo errepikakorra.

Bestalde, ezin ahaz liteke aliterazioa bezalako irudien presentzia afektu eta efektu-sortzailea Axularrek erabili edergarri fonologikoen artean. Ezaguna denez, aliterazio hitzaren egungo erabilpenak nasaiki gainditzen du erretorika klasikoaren kategorizazio hertsia (Lázaro Carreter 1990, 232-hk). Halere, esan beharrekoa da irudi hori elkarren ondoko hitzen hasierako kontsonantearen edo silaben errepikapenera mugatzen zela zioen kontzepzioa bera lasaitasunez hartua izan ohi zela idazte orduko praktika konkretuan, aliterazioa eskuarki kategorizazio bezala baino gehiago baliabide gisa hartzen baitzen idazleen artean. Horrela, 
testuan isuritako mezuaren izaerarekin estuki lotuta agertzen zen baliabide hau, efektu afektibo-psikologikoak lortzeko asmoarekin hain zuzen.

Ildo horretatik, eta kasuistikaren barnean, nabarmentzekoa da urdazubiarrak kontsonante dardarkariaz egiten duen erabilera "izugarria", isladatu baino gehiago "rr"-aren aliterazioak areagotu egiten baitu egoeraren dramatismoa. Jakina, ez dira gutxiestekoenak infernuaren ingurukoak :

Lurrean barrena, gure azpian, lurrac duen leccuric beherenean, centruaren aldean, lurraren hondarrean $[\ldots]$ ( 580 or. $)$.

Axularren planteamendu elokutiboaren ezaugarri garrantzitsuenekin bukatzeko, pare bat hitz baino ez Axularren pasarte zenbaitetan usnatzen den beste fenomeno (edergarri ?) batez.

Testura hurbiltzen den irakurleari behin baino gehiagotan irudi dakioke lerro dexente Axularri belarrian zerabilkion konpas edo musika akonpasatu antzeko batez burutuak daudela, zenbaitetan perpaus neurtuen inpresioa ematen baitu Axularren prosak. Eta ez gara homosilabismo estu-estuaz mintzatzen ari -aski garbi utzia baitzuen erretorika eklesiastikoak silaba-kontaketaren haurkeria ${ }^{18}$, ohiturak eta beste hainbat faktorek sortutako neurkera mekanismoaz baizik, nolabaiteko silaba-berdintasuna edo ahalbidetzen zuenaz hain zuzen.

Baina horretan ba bide zuen eraginik garaiko literatura idatziak ere. Bestelako literaturarik ez egotean (debekatua, arbuiatua edota gutxietsia) eta arrakastatsuki hadatzen ari zen gehienak parametro zehatzeko ezaugarriei erantzuten zienez, pentsatzekoa da kontrarreformako euskal botere faktikoen indarrak funtsezko lana egin zuela eta kultur eredu konkretu hauek ezartzean, irakurle eta idazleen kontzientzia-ezpain-idazlumetan ezartzea lortu zuela.

Oraindik ahozkotasunean murgilduta jarraitzen zuen gizartearen erreferentzietan bilatu beharko genituzke, hortaz, prosaren erritmo beharra azaltzeko beste elementuak. Ildo horretatik, Etxepareren, Ziburuko Etxeberriren eta garai hartako ahozko poesiaren ezaugarria den neurkera ereduaren oihartzun nabarmena du Axularren prosak ere. Baina "neurkera" hitza bortitzegia denez gero prosaren esparruko erritmoa definitzeko, erretorikaren esparruko "musika proportzioa" adiera ${ }^{19}$ erabil genezake oihartzun eta zentzazio proportzionatu hori adierazteko.

Oro har, oinarrizko "neurri unitate" edo proportzio horiek lau silabako hitzen edo hitz multzoen inguruan sortuko lirateke. Horrela, Axularren liburuaren izenburu ondoko lerro deskribatzaileetan beretan neurkera moduko horren oihartzuna aurki daiteke : "Bi par-te-tan/par-ti-tu-a/(eta) be-re-zi-a", "[...] e-mai-ten da/adi-tze-ra/zen-bat kal-te [...]", etab.

Pasarte landuenetako ereduak ere eredu horren arabera moldatuko dira sarri askotan, betiere aipatu unitate horiek nagusi izango direlarik. Etxauzi egindako laudorioen atalean, guztien laburbiltze prosopopeiko erritmikoa (anaforikoa eta neurtua) aurkeztean, nabarmena da eredua :

Be-rac di-ra/be-re bu-ruz/as-co go-ra/min-tço :

be-rac di-ra/be-re bai-than/as-co clar/e-ta o-cen.

Utz di-tça-dan/be-raz nic hec,/ hu-tsic/ez-ta-gui-dan ( 9 or.) 
Berdintsu esan liteke "Irakurtzaileari" izeneko gutunaren hasierako lehenengo lerroei buruz ( 15 or.), lau silabakoak baitira oinarrizko erritmoan agertzen diren unitateak : "E-gun ba-tez,/ kon-pa-iñi-a/on ba-te-an,/ eus-cal-du-nic/bai-cen etcen/leccuan/nen-go-e-la [...]", "e-gu-ne-tic/e-gu-ne-ra,/bi-ha-rre-tic/bi-ha-rre$\mathrm{ra} /$ lu-ça-tce-ac", etab.

Halaber, eta silaba kopuruari dagokionez, aipagarriak dira garaiko poesia edo bertsoen arloko "neurkerak" (4+4+4+3 egiturakoak). Erraz asko identifika litezke, esaterako, horrelako testu segmentuak -gehiago ala gutxiago bortxatuz-, eta egingo genuke erosotasun handiz tarteka litezkeela Etxepareren eta Ziburuko Etxeberriren pasarteen artean, hala nola "e-tçu-e-la,/deu-sec e-re/han-bat cal-te/egui-ten" (15 or.) testu-segmentua edota infernuaren deskribapenean agertzen den "be-hin e-re/hotz-ten e-ta/i-raun-gui-tcen/ez-te-na" (580 or.) bezalakoak.

Hauek dira, bada, prosa berezia lortzeko Axularrek erabiltzen dituen baliabide eta edergarri erretoriko garrantzitsuenak. Ugariak, aberatsak eta desberdinak, zalantzarik gabe. Baina guztiarekin ere, ez da ahaztu behar elementu horien guztien erabilera, uztartze eta ehuntzetik sortzen diren tonalitatea, erritmoa eta estiloa direla azken buruan Axularren prosa zaporetsu, original eta baliagarri egiten dutenak.

Patxi SALABERRI MUÑ̃OA $U P V / E H U$

\section{Bibliografia}

Axular, Guero. Bi partetan partitua eta berecia..., Bordele, 1643 (faksimila : Bilbo, Euskaltzaindia, 1988).

Cerdan, Francis, 1988, "El sermón barroco : un caso de literatura oral", Edad de Oro, VII, 59-68.

Ciceron, Obras completas, I eta II, (itzulp : M. Menéndez Pelayo, Madrid, Suc. de Hernando, 1913 eta 1914).

Dijk, T. A. van, 1983, La ciencia del texto. Un enfoque interdisciplinario, Barcelona, Paidós.

García de Enterria, Ma Cruz, 1993, "Lectura y rasgos de un público", Edad de Oro XII, 119-130.

Granada, Luis de, Retórica Eclesiástica o de la manera de predicar, in Obras del V.P.M. Fray Luis de Granada, III, Madrid, Imprenta de la Publicidad (BAE XI), 1945, 488-642 or.

Kayser, W., 1992, Interpretación y análisis de la obra literaria, Madrid, Gredos, 4. ed.

Larramendi, M., Diccionario trilingüe, 1745, San Sebastian.

Lázaro Carreter, F., 1990, De Poética y Poéticas, Madrid, Cátedra.

Materre, E., Dotrina Christiana, Bordele, J. Millanges, 1623.

Mayoral, J. A., 1994, Figuras retóricas, Madrid, Síntesis.

Menéndez Pidal, R., 1947, "El lenguaje del siglo XVI", La lengua de Cristóbal Colón, Buenos Aires, Espasa Calpe.

Mortara Garavelli, B., 1991, Manual de retórica, Madrid, Ed. Cátedra.

Terrones del Caño, Fco., Instrucción de Predicadores, Granada, 1617, [1960, Madrid, Espasa-Calpe].

Villasante, Luis, 1972, Axular : Mendea, Gizona, Liburua, Ed. Franciscana Aranzazu, Oñati. 


\section{Notes}

1 - Berbaldiaren eduki argumentalaren banaketa perpaus gramatikalen esparrua gainditu dezaketen unitateen arabera burutzen da erretorika klasikoan. Unitate horiek periodo izena hartu ohi dute eta bi unetan garatzen dira : protasian (tentsioaren sorrera) eta apodosian (pentsamenduaren ixtea, perpausaren lasaitasuna eta osotasuna zekarrena hain zuzen). Ideia nagusia lehen zatian gertatuz gero, periodoa beheranzkoa izaten zen ; alderantziz, hau da, ideia tentsio-sortzailea bukaeran egonik, periodoa goranzkoa izan ohi zen. Egitura mota hauek luzera ezberdinetakoak izan ohi dira eta osagarriak, gogoratu beharrik ez dago, ohikoak diren pentsamendu-elementu txikiago batzuekin konformatzen dira (kolon eta komma). Periodoaren elementu erritmikoa, hura armonikoki bukatzeko prestatzen zena alegia, kadentzia izenekoaren bidez burutzen zen. Erretorika klasikoan bizpahiru oinetako sekuentzia ohi zen amaiera hori. Alabaina, kadentziak bilakaera berezia izan zuen historikoki. Oradore greziar eta erromatarren kadentzia mota silaben luzelaburtasunaren bidez egiten bazen ere, kantitatearen ezaugarria galdu ahala, erritmoak ere azentuaren neurria hartzen hasi zen eta kadentzia kuantitatiboak, ondorioz, kadentzia toniko bilakatu ziren, harrezkero zeharo hedatuko zen cursus erritmikoaren kontzeptua zabalduko zelarik.

2 - "Sólo podremos hablar de estructuras epeciales [...] cuando se da una cierta regularidad convencionalmente determinada y, por lo tanto, no casual" (Dijk 1983, 130).

3 - Eredua garbiago ikus dadin, jatorrizko testuan ez bezala emango dugu puntuaketa mota.

4 - "ceren hec açala eta lorea beçala baitira" ( 20 or.), "uraren pare gara" (61 or.), "deabruaren paretsu eguiten da" (98 or.) modukoak.

5 - "Son soluciones óptimas -sólo "a posteriori" aceptadas dogmáticamente- para determinadas empresas oratorias, y siempre pueden surgir de nuevo con espontaneidad, sin imitación consciente" (Kayser 1992, 348).

6 - Nahi izan balu ere, euskararen ezaugarriak medio, Axularrek ezin aplika zezakeen modu zuzenean latinezko testuetan (bokale luze-laburren sistemagatik) antzematen zen kadentzia eta inguruko erdaretan azentuagatik egin ohi zen cursus -a. Izan ere, euskararen bokaleen kantitate-batasunak (ez dago luze-laburrik bereizterik) eta hitzen azentu trinko ezak ezinbestean bultzatu zuten idazlea, izandako prestakuntza erretorikoaz baliatu nahi duen idazlea beste bide batzuk bilatzera, urratzera eta, konpentsazioaren legeagatik, ordurarteakoak ere beste modu batez planteatzera. Ildo horretatik, badirudi Axular izan zela bide horiek espreski eta kontzienteki aztertu zituen lehen idazlea, idazle ezaguna behinik behin.

7 - Inoiz gerta daiteke elementu kuantitatiboa gradazio logiko edota denborazkoarekin bat ez etortzea (zahartzaroa gaztaroaren ondotik dator, esaterako). Horrelakoetan, gogoratu beharrik ez dago, halabeharrez erabakitzen du Axularrek elementu logikoaren alde.

8 - Zizeronen jokamoldea jarri ohi zen eredu gisa : “...para que también la acentuación y el ritmo contribuyan a realzar el tono armónico del pensamiento vertido en la sintaxis, Cicerón se vale de elementos métricos que concluyan y cierren el final de la cláusula. Así evitará ordinariamente terminar sus frases con palabras muy largas o demasiado cortas. Sus preferencias se inclinan por las palabras de tres o cuatro sílabas" (Terrones del Caño, Instrucción, 240)

9 - Gaur egun irudi isotaktikoen artean kokatzen den arren, terminologia arazoak ahalik gehien ekidin ahal izateko, paralelismoa ondoko definizio honen arabera erabiliko da hemen : "es la colocación de sonidos, de palabras, de formas gramaticales, de estructuras sintácticas, de cadencias rítmicas : de los componentes, en suma, de todos los niveles de la organización del discurso" (Mortara Garavelli 1991, 233). Funtzionalki, paralelismoaren erabilerak mezuaren intentsifikazioa lortzea bilatzen badu ere, ikuspuntu estilistikotik parametro erritmiko bereziz tindatzen du prosa.

10 - "Las estructuras retóricas se basan [...] en estructuras gramaticales, por lo que resulta apropiado basar su sistemática en los diferentes niveles habituales como la fonología, la morfología, el léxico, la sintaxis y la semántica" (Dijk 1983, 128).

11 - "hotça, motça" (606 or.), "icena [...], içana" (7 or.), "othoi, orhoit" (20 or.), "erran-merranak" (312 or.,...), "zintki eta fintki” (460 or.,...), "gor eta sor" (555 or.), "irautez eta iraupez" (608 or.), "onhest, modest" (177 or.), etab.

12 - Esparru honetan Axularri inoiz xede transdialektalik ikusi bazaio ere - "badakit [...] ezin heda naitekeiela euskarako mintzatze molde guztietara" delakoan oinarrituz- haren praktika erretorikoak garbi asko erakusten du gakoa ez datzala horretan. Izan ere, euskalki aniztasunaz ohartuta egoteak ez zekarren berez eta ezinbestez, ondorio gisa, ahalik gehienen irakurketarako baliagarri izan zitekeen hizkuntz planteamendu oro-hartzailerik, nahiz eta arlo horretan ere lagun zezakeen. 
13 - "Urliac eta sandiac" (312 or.), "fermo eta fintco" (455 or.), "argui [...] eta clar" (568 or.),"sainduqui eta prestuqui" (477-478 or.), "justuqui eta çucentqui" (608 or.), "sendoric eta salboric" (560 or.), etab. Gehien errepikatzen diren fosilizatu horietakoen artean, "atseguinac eta placerac" bikotea legoke, hogei bat aldiz agertzen baita. Era berean, "pena eta atsecabe", "calte eta atsecabe", "falta [...], hobena" bezalakoak etengabe azaltzen direla esan daiteke. Adierazgarria da, ildo horretatik, honako hau : "damu eta atsecabe, pena eta dolore, min eta oiñhace" ( 589 or.).

14 - Kontraste aipagarrienak antonimo klasikoen bidez datoz : gaiztoak-onak, infernua-zerua, bertutea-bekatua, eder-itsusi, triste-alegera, pobre-aberats, etab.

15 - Egitura kiasmikoa ere loturik doa testuan nabarmentzen den planteamendu antitetikoarekin, izatez testu segmentuen ispilu eraketa erakutsi ohi baitu irudi honek : "Çahar gaixtoac, çahartuagatic, badu gogoa, indarra çaica falta" (93 or.)

16 - Honela uler liteke hoskidetasuna : “[...] regulación estricta en el discurso en verso de los fenómenos de Similicadencia (Homeotéleuton y Homeóptoton), cuya realización queda restringida a unos lugares precisos de las secuencias versales : las correspondientes a la o las sílabas finales de verso o hemistiquio" (Mayoral 1994, 68).

17 - Jakina, horrelakoetan neurkeraz baino gehiago pautaz mintzatu beharko genuke, "erregulartasuna" autoreak berbaldiarekiko duen izpiritu edo zentzu musikalak bideratuko bailuke hein handi batean, eta ez silaba kopuru zehatzak.

18 - "[...] no se ha de hacer con la enumeración de las sílabas, que sería cosa pueril, sino con el uso y el ejercicio que facilitan, que por cierto sentimiento y gusto del entendimiento, percibido por el oído, se haga un miembro igual al antecedente" (Granada, Retórica, 596b).

19 - "[...] se procura que todas las palabras [...] estén distribuidas con cierta proporcion musical" (Terrones del Caño, Instrucción, 245). 